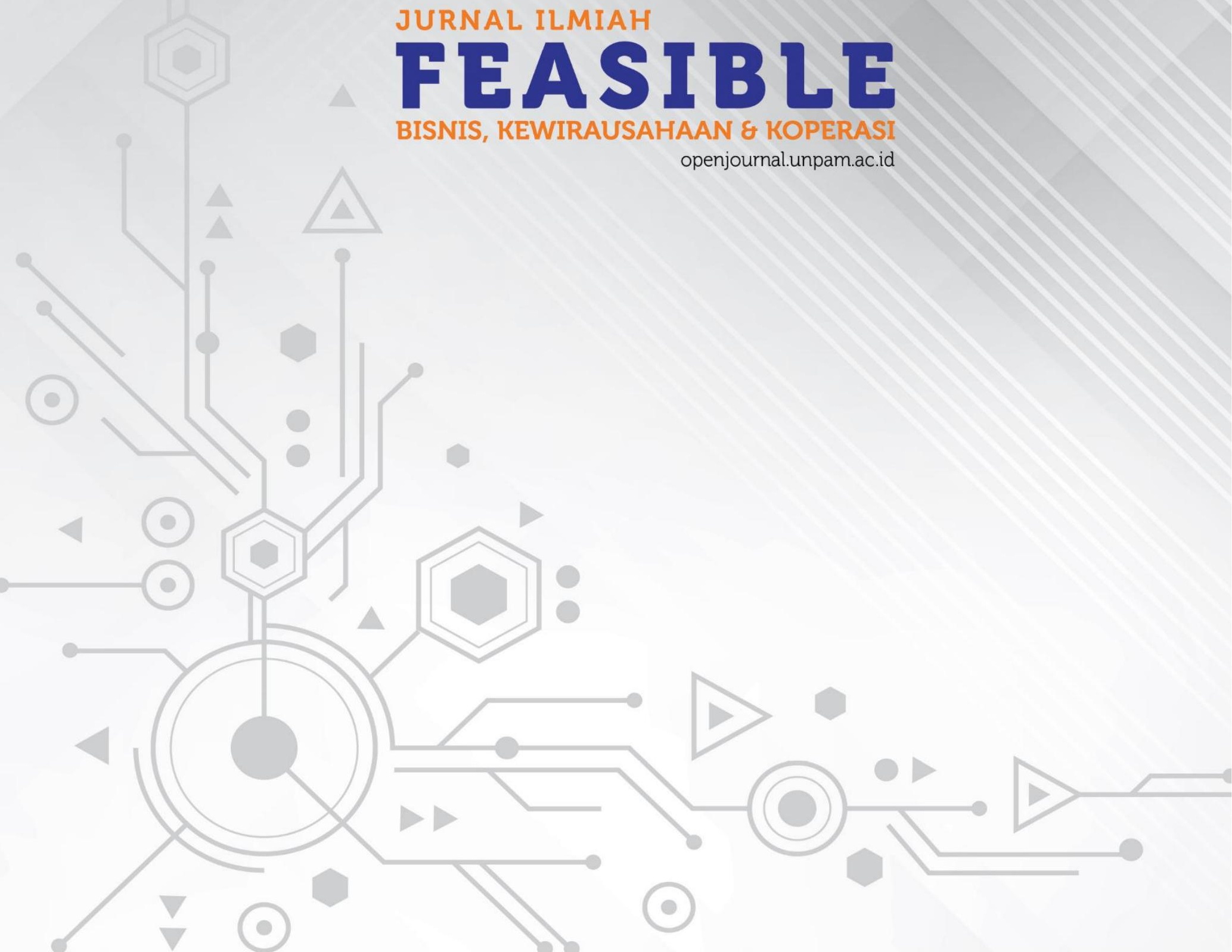





\title{
ANALISIS PENGARUH RASIO PERPUTARAN PIUTANG DAN RASIO PERPUTARAN PERSEDIAAN TERHADAP RASIO PROFITABILITAS YANG DIPROYEKSIKAN DENGAN RETURN ON ASSETS (ROA) PADA PT. KALBE FARMA, Tbk
}

\author{
Jamaludin \\ Fakultas Ekonomi, Universitas Pamulang \\ dosen01020@unpam.ac.id
}

\begin{abstract}
Abstrak
Penelitian ini bertujuan untuk mengetahui pengaruh rasio Perputaran Piutang dan Rasio Perputaran persediaan terhadap rasio profitabilitas yang diproyeksikan dengan Rasio Profitabilitas (Return On Assets (ROA)) pada PT. Kalbe Farma, Tbk. Metode yang digunakan yaitu pengujian statistik dengan analisis regresi linier berganda (multiple regression analysis), uji asumsi klasik, uji t dan uji $F$. Objek dalam penelitian ini adalah $P T$. Kalbe Farma, Tbk periode 2008 - 2017. Sedangkan indikator yang digunakan adalah Rasio Rasio Perputaran Piutang dan Rasio Rasio Perputaran persediaan sebagai variabel independen atau variabel bebas dan Rasio Profitabilitas (Return On Assets (ROA)) sebagai variabel dependen atau variabel terikat. Hasil uji t diperoleh bahwa secara parsial Rasio Rasio Perputaran Piutang tidak berpengaruh terhadap Rasio Profitabilitas (Return On Assets), sedangkan Rasio Rasio Perputaran persediaan Rasio Rasio Perputaran persediaan berpengaruh positif dan signifikan terhadap Rasio Profitabilitas (Return On Assets). Hasil uji F diperoleh bahwa Rasio Rasio Perputaran Piutang dan Rasio Rasio Perputaran persediaan berpengaruh positif dan signifikan terhadap rasio profitabilitas (Return On Assets) dengan nilai $F_{\text {hitung }}=7,928>F_{\text {tabel }}=4,737$ serta nilai signifikan sebesar $0,016<0,05$. Hal ini didukung dengan nilai koefisien determinasi (KD) sebesar 0,694 yang artinya 69,4\% Rasio Profitabilitas (Return On Assets (ROA))dipengaruhi oleh variabel rasio Rasio Rasio Perputaran Piutang dan rasio Rasio Rasio Perputaran persediaan, dan sisanya sebesar 30,6\% dipengaruhi oleh variabel lain diluar penelitian.
\end{abstract}

Kata Kunci: Rasio Perputaran Piutang ; Rasio Perputaran persediaan ; Rasio Profitabilitas

\begin{abstract}
This study aims to determine the effect of accounts receivable turnover ratio and inventory turnover ratio on the projected profitability ratio with the profitability ratio (Return on Assets (ROA)) at PT. Kalbe Farma, Tbk. The method used is statistical testing with multiple regression analysis (multiple regression analysis), classical assumption test, $t$ test and $F$ test. The object in this study is PT. Kalbe Farma, Tbk for the period 2008 - 2017. While the indicators used are the Accounts Receivable Turnover Ratio and Inventory Turnover Ratio as an independent variable or independent variable and the Profitability Ratio (ROA) as the dependent variable or dependent variable. The t test results show that partially the Accounts Receivable Turnover Ratio has no effect on the Profitability Ratio (Return on Assets), while
\end{abstract}


the inventory turnover ratio has a positive and significant effect on the profitability ratio (Return on Assets). The results of the F test show that the Accounts Receivable Turnover Ratio and Inventory Turnover Ratio have a positive and significant effect on the profitability ratio (Return on Assets) with the value of Fcount $=7.928>$ Ftable $=4.737$ and $a$ significant value of $0.016<0.05$. This is supported by the coefficient of determination (KD) of 0.694, which means $69.4 \%$ of the profitability ratio (ROA) is influenced by the ratio of the Accounts Receivable Turnover Ratio and Inventory Turnover Ratio, and the remaining 30.6\%. influenced by other variables outside the study.

Keywords: Receivables Turnover Ratio; Inventory Turnover Ratio; Profitability Ratio

\section{PENDAHULUAN}

\section{Latar Belakang}

Secara umum, keberhasilan suatu perusahaan dalam menjalankan aktivitasnya seringkali didasarkan pada tingkat laba yang diperoleh. Akan tetapi, laba yang besar belum tentu menjadi ukuran bahwa perusahaan tersebut telah bekerja secara efisien. Tingkat efisiensi baru diketahui dengan cara membandingkan laba yang didapat dengan kekayaan atau modal yang menghasilkan laba tersebut. Menurut Kasmir (2015:196) untuk mengukur tingkat keuntungan perusahaan itu sendiri bisa digunakan rasio keuntungan atau rasio profitabilitas yang dikenal juga dengan nama rasio rentabilitas. Sedangkan rasio profitabilitas merupakan rasio untuk menilai kemampuan perusahaan dalam mengukur dan mencari keuntungan. Penelitian ini menggunakan Rasio Profitabilitas yaitu Rasio Profitabilitas (Return On Assets (ROA)), karena Rasio Profitabilitas (Return On Assets (ROA)) menunjukkan keefisienan perusahaan dalam mengelola seluruh aktiva. Rasio Profitabilitas (Return On Assets (ROA)) mengukur tingkat pengembalian total aktiva setelah beban bunga dan pajak.
Semakin besar Rasio Profitabilitas (Return On Assets (ROA)), berarti semakin efisien penggunaan aktiva perusahaan atau dengan kata lain dengan jumlah aktiva yang sama bisa dihasilkan laba yang lebih besar, dan sebaliknya.

Setiap perusahaan dalam menjalankan aktivitas bisnisnya membutuhkan dana yang tertanam dalam modal kerja. Modal kerja itu sendiri mengandung elemenelemen aktiva lancar, salah satu diantaranya terdiri dari piutang dan persediaan, elemen tersebut sangat dibutuhkan dalam setiap operasi perusahaan sehari-hari.

Persediaan merupakan unsur dari aktiva lancar yang merupakan unsur yang aktif dalam operasi perusahaan yang secara terus menerus diperoleh, diubah dan kemudian dijual kepada konsumen. Untuk mem-percepat pengembalian kas melalui penjualan maka diperlukan suatu Rasio Rasio Perputaran persediaan yang baik. Pada prinsipnya Rasio Rasio Perputaran persediaan mempermudah atau memperlancar jalannya operasi perusahaan yang harus dilakukan secara berturut-turut untuk memproduksi barang-barang serta mendistribusikannya kepada pelanggan. 
Semakin tinggi Rasio Rasio Perputaran persediaan barang, maka semakin tinggi biaya yang dapat ditekan sehingga semakin besar perolehan laba suatu perusahaan. Sebaliknya, jika semakin lambat Rasio Rasio Perputaran persediaan barang, semakin kecil pula laba yang diperolehnya (Raharjaputra, 2009:132).

Salah satu strategi alternatif yang dipakai di setiap perusahaan guna memperlancar penjualan hasil produksinya adalah dengan melakukan penjualan secara kredit pada produk atau jasa yang ditawarkan kepada calon pelanggan. Sistem penjualan secara kredit berbentuk piutang usaha. Piutang usaha tersebut akan bertransformasi menjadi kas pada saat piutang tersebut jatuh tempo dan dilunasi oleh pelanggan. Namun pembayaran piutang yang diterima di kemudian hari akan menimbulkan resiko bagi perusahaan, baik resiko keterlambatan pelunasan piutang oleh pelanggan, hingga resiko tidak terbayarnya piutang tersebut. Pengelolaan piutang dalam suatu perusahaan menyangkut pada Rasio Rasio Perputaran Piutang. Semakin tinggi Rasio Rasio Perputaran Piutang, maka semakin meningkatnya profitabilitas perusahaan karena jumlah piutang yang tak tertagih semakin kecil. Akan tetapi Rasio Rasio Perputaran Piutang yang terlalu tinggi dapat menurunkan profitabilitas, hal ini dikarenakan dana yang tertanam dalam piutang terlalu kecil yang berarti volume penjualan kredit juga terlalu kecil dan profitabilitas ikut menurun. Dengan demikian Rasio Rasio Perputaran Piutang harus mendapatkan perhatian khusus dari manajer perusahaan.

Berikut adalah data Rasio Rasio Perputaran Piutang , Rasio Rasio Perputaran persediaan dan Rasio Profitabilitas (Return On Assets (ROA))pada PT. Kalbe Farma, Tbk adalah sebagai berikut:

\begin{tabular}{|c|c|c|c|}
\hline $\begin{array}{r}\text { Tabel } 1.1 \\
\text { Piuta } \\
\text { persed } \\
\text { (Retur } \\
\text { Farı }\end{array}$ & $\begin{array}{l}\text { Data Rasi } \\
\text {, Rasio R } \\
\text { an dan Ra } \\
\text { On Assets } \\
\text {, Tbk Peri }\end{array}$ & $\begin{array}{l}\text { Rasio Per } \\
\text { sio Perput } \\
\text { io Profita } \\
\text { ROA)) PT } \\
\text { de 2008-2 }\end{array}$ & $\begin{array}{l}\operatorname{taran} \\
\text { an } \\
\text { itas } \\
\text { albe } \\
7\end{array}$ \\
\hline Periode & $\begin{array}{l}\text { Rasio } \\
\text { Perputaran } \\
\text { Piutang } \\
\text { (kali) }\end{array}$ & $\begin{array}{c}\text { Rasio } \\
\text { Perputaran } \\
\text { persediaan } \\
\text { (kali) }\end{array}$ & $\begin{array}{c}\text { ROA } \\
(\%)\end{array}$ \\
\hline 2008 & 8,73 & 2,69 & 12,39 \\
\hline 2009 & 8,50 & 2,89 & 14,33 \\
\hline 2010 & 8,29 & 3,25 & 18,29 \\
\hline 2011 & 7,81 & 3,29 & 18,41 \\
\hline 2012 & 8,18 & 3,72 & 18,85 \\
\hline 2013 & 8,10 & 3,22 & 17,41 \\
\hline 2014 & 7,73 & 2,89 & 17,07 \\
\hline 2015 & 7,61 & 3,05 & 15,02 \\
\hline 2016 & 7,77 & 3,11 & 15,44 \\
\hline 2017 & 7,33 & 3,00 & 14,76 \\
\hline
\end{tabular}

Berdasarkan data di atas, dilihat dari tingkat Rasio Rasio Perputaran Piutang PT. Kalbe Farma, Tbk mengalami fluktuatif dan cenderung menurun dari tahun ke tahunnya mulai dari tahun 2008 sampai dengan tahun 2017. Nilai Rasio Rasio Perputaran Piutang yang paling tinggi terjadi pada tahun 2008 yaitu sebesar 8,73 kali. Sedangkan nilai Rasio Rasio Perputaran Piutang yang paling rendah terjadi pada tahun 2017 yaitu sebesar 7,33 kali. Peningkatan Rasio Rasio Perputaran Piutang lebih disebabkan karena menurunnya investasi pada piutang yang disinyalir karena pembayaran piutang yang 
cukup tinggi. Selain hal tersebut, faktor lain penyebab peningkatan perputaran piutang karena investasi yang cukup tinggi di persediaan yang menyebabkan tingginya penjualan PT. Kalbe Farma, Tbk. Sedangkan faktor yang menyebabkan menurunnya Rasio Rasio Perputaran Piutang lebih banyak disebabkan karena penjualan kredit yang cukup tinggi.

Dilihat dari tingkat Rasio Rasio Perputaran persediaan PT. Kalbe Farma, Tbk mengalami fluktuatif dari tahun 2008 sampai dengan tahun 2017. Nilai Rasio Rasio Perputaran persediaan yang paling tinggi terjadi pada tahun 2012 yaitu sebesar 3,72 kali. Sedangkan nilai Rasio Rasio Perputaran persediaan yang paling rendah terjadi pada tahun 2008 yaitu sebesar 2,69 kali. Apabila rasio yang diperoleh tinggi, ini menunjukkan perusahaan bekerja secara efisien dan likuid persediaan semakin baik. Demikian pula apabila Rasio Rasio Perputaran persediaan rendah berarti perusahaan bekerja secara tidak efisien atau tidak produktif dan banyak barang persediaan yang menumpuk.

Dilihat dari nilai Rasio Profitabilitas (Return On Assets (ROA)) PT. Kalbe Farma, Tbk juga mengalami fluktuatif dari tahun 2008 sampai dengan tahun 2017. Nilai Rasio Profitabilitas (Return On Assets $(R O A)$ ) yang paling tinggi terjadi pada tahun 2012 yaitu sebesar 18,85\%. Sedangkan nilai Rasio Profitabilitas (Return On Assets (ROA)) yang paling rendah terjadi pada tahun 2008 yaitu sebesar 12,39\%. Peningkatan Rasio
Profitabilitas (Return On Assets (ROA))pada PT. Kalbe Farma disebabkan karena adanya pemanfaatan aset untuk lebih produktif melalui perputaran aset seperti Rasio Rasio Perputaran Piutang dan persediaan serta perputaran kas yang cukup tinggi. Sedangkan penurunan Return on Assets (ROA) pada PT. Kalbe Farma, Tbk disebabkan karena kenaikan beban penjualan, administrasi dan umum serta kurang efektifnya pemanfaatan aset yang dimiliki.

Persediaan dan piutang harus dikelola dengan baik secara efektif dan efisien, karena kedua aktiva lancar tersebut merupakan unsur yang sangat penting dalam modal kerja. Oleh karena itu, kemampuan manajemen perusahaan dalam mengelola modal kerja dapat mempengaruhi kestabilan tingkat profitabilitas perusahaan tersebut. Jadi, pentingnya melakukan evaluasi akan tingkat profitabilitas terkait keberadaan perusahaan tersebut dalam hubungannya terutama dengan pihak eksternal.

PT. Kalbe Farma, Tbk adalah salah satu perusahaan farmasi yang sudah terdaftar di Bursa Efek Indonesia. Perusahaan ini merupakan perusahaan internasional yang memproduksi farmasi, suplemen, nutrisi dan layanan kesehatan yang bermarkas di Jakarta, Indonesia. Perusahaan ini menghasilkan berbagai macam-macam bahan farmasi. Peneliti tertarik memilih perusahaan ini karena dikenal masyarakat luas. 
Dengan demikian, maka penulis tertarik untuk mengadakan penelitian, dimana judul yang akan dibahas adalah "Analisis Pengaruh Rasio Rasio Perputaran Piutang Dan Rasio Rasio Perputaran persediaan Terhadap Rasio Profitabilitas (Return On Assets (ROA)) Pada PT. Kalbe Farma, Tbk."

\section{Perumusan Masalah}

Sesuai dengan latar belakang diatas, adapun rumusan masalah dalam penelitian ini adalah sebagai berikut:

1. Bagaimana pengaruh Rasio Perputaran Piutang terhadap Rasio Profitabilitas (Return On Assets (ROA)) pada PT. Kalbe Farma, Tbk periode 2008-2017?

2. Bagaimana pengaruh Rasio Perputaran persediaan terhadap Rasio Profitabilitas (Return On Assets (ROA)) pada PT. Kalbe Farma, Tbk periode 2008-2017?

3. Bagaimana pengaruh Rasio Perputaran Piutang dan Rasio Perputaran persediaan terhadap Rasio Profitabilitas (Return On Assets (ROA)) pada PT. Kalbe Farma, Tbk periode 2008-2017?

\section{Tujuan Penelitian}

Adapun tujuan dari penelitian ini adalah sebagai berikut:

1. Untuk mengetahui pengaruh Rasio Perputaran Piutang terhadap Rasio Profitabilitas (Return On Assets (ROA)) pada PT. Kalbe Farma, Tbk periode 2008-2017.

2. Untuk mengetahui pengaruh Rasio Perputaran persediaan terhadap Rasio Profitabilitas (Return On Assets (ROA)) pada PT. Kalbe Farma, Tbk periode 2008-2017.

3. Untuk mengetahui pengaruh Rasio Perputaran Piutang dan Rasio Perputaran persediaan terhadap Rasio Profitabilitas (Return On Assets (ROA)) pada PT. Kalbe Farma, Tbk periode 2008-2017

\section{Manfaat Penelitian}

Penelitian ini diharapkan dapat memberikan manfaat bagi semua pihak antara lain:

1. Bagi Peneliti

Penelitian ini diharapkan menambah wawasan ilmu pengetahuan tentang Pengaruh Rasio Perputaran Piutang dan Rasio Perputaran persediaan terhadap Rasio Profitabilitas (Return On Assets (ROA)) dan dapat mengaplikasikannya pada perusahaan.

\section{Bagi Pihak lain}

Bagi pihak lain, Penulis mengharapkan agar hasil penelitian dapat dijadikan sebagai salah satu informasi tambahan yang berguna sebagai bahan bacaan untuk menambah wawasan dibidang Mana-jemen khususnya mengenai masalah Rasio Perputaran Piutang, Rasio Perputaran persediaan dan Rasio Profitabilitas (Return On Assets (ROA)).

3. Bagi Perusahaan

Sebagai bahan pertimbangan dan masukan bagi perusahaan untuk lebih baik lagi dalam mengelola Rasio Perputaran Piutang dan Rasio 
Perputaran per-sediaannya untuk mencapai Profitabilitas yang maksimal.

\section{Kajian Literatur}

\section{Manajemen Keuangan}

Manajemen keuangan adalah suatu kegiatan perencanaan, penganggaran, pemeriksaan, pengelolaan, pengendalian, pencarian dan penyimpanan dana yang dimiliki oleh suatu organisasi atau perusahaan.

Menurut Fahmi (2016:2) Manajemen keuangan merupakan penggabungan dari ilmu dan seni yang membahas, mengkaji dan menganalisis tentang bagaimana seorang manajer keuangan dengan mempergunakan seluruh sumberdaya perusahaan untuk mencari dana, mengelola dana, dan membagi dana dengan tujuan mampu memberikan profit atau kemakmuran bagi para pemegang saham dan suistainability (keberlanjutan) usaha bagi perusahaan.

Menurut Sutrisno (2013:3) Manajemen keuangan atau sering disebut pembelanjaan dapat diartikan sebagai semua aktivitas perusahaan yang berhubungan dengan usaha-usaha mendapatkan dana perusahaan dengan biaya yang murah serta usaha untuk menggunakan dan mengalokasikan dana tersebut secara efisien.

Berdasarkan penjelasan diatas dapat disimpulkan bahwa manajemen keuangan adalah segala kegiatan ataupun usaha dalam mendapatkan dana dan penggunaan dana tersebut seefisien mungkin dalam mencapai tujuan suatu perusahaan ataupun organisasi.

\section{Laporan Keuangan}

Laporan keuangan merupakan suatu informasi yang menggambarkan kondisi keuangan suatu perusahaan, dan lebih jauh informasi tersebut dapat dijadikan sebagai gambaran kinerja keuangan perusahaan tersebut. Menurut Kasmir (2015:7) Laporan keuangan adalah laporan yang menunjukkan kondisi keuangan perusahaan pada saat ini atau dalam suatu periode tertentu.

Menurut Sutrisno (2013:9) Laporan keuangan disusun dengan maksud untuk menyediakan informasi keuangan suatu perusahaan kepada pihak-pihak yang berkepentingan sebagai bahan pertimbangan di dalam mengambil keputusan.

\section{Rasio Perputaran Piutang (Receivable Turnover)}

Menurut Warren, et. all (2008:404) menyatakan bahwa yang dimaksud dengan piutang adalah sebagai berikut: "Piutang meliputi semua klaim dalam bentuk uang terhadap pihak lainnya, termasuk individu, perusahaan atau organisasi lainnya." Sedangkan menurut Jusup (2005:52) "Pada umumnya, piutang timbul karena adanya transaksi penjualan secara kredit.”

Dari kedua definisi yang telah diungkapkan diatas, dapat disimpulkan bahwa yang dimaksud dengan piutang adalah semua tuntutan atau tagihan kepada pihak lain dalam bentuk uang atau barang 
yang timbul dari adanya penjualan secara kredit. Piutang merupakan salah satu elemen modal kerja yang paling dibutuhkan dalam perusahaan yang melayani penjualan secara kredit. Suatu perusahaan yang memiliki piutang berhubungan erat dengan volume penjualan. Oleh sebab itu piutang perlu mendapat perhatian khusus dalam pengelolaannya. Pengelolaan piutang dalam suatu perusahaan menyangkut pada pengelolaan Rasio Perputaran Piutang .

Menurut Kasmir (2015:176) Rasio Perputaran Piutang merupakan rasio yang digunakan untuk mengukur berapa lama penagihan piutang selama satu periode atau berapa kali dana yang ditanam dalam piutang ini berputar dalam satu periode.

Menurut Harrison Jr et.al.(2013:261) Rasio Perputaran Piutang usaha (receivable turnover) adalah rasio untuk mengukur kemampuan untuk menagih kas dari pelanggan. Secara umum, semakin tinggi rasio, semakin baik. Akan tetapi, Rasio Perputaran Piutang usaha yang terlalu tinggi mungkin mengindikasi bahwa kredit terlalu ketat dan mungkin menyebabkan kehilangan penjualan dari pelanggan utama.

Dengan menghitung tingkat Rasio Perputaran Piutang (receivable turnover) dapat menilai posisi piutang dan taksiran waktu pengumpulannya yaitu dengan membagi total penjualan kredit (netto) dengan rata-rata piutang. Rata-rata piutang dapat dihitung secara tahunan yaitu saldo awal tahunan ditambah saldo akhir tahun dibagi dua. Periode Rasio Perputaran
Piutang tergantung bagaimana perusahaan meng-aturnya, dan tergantung pada panjang pendeknya dengan ketentuan waktu yang dipersyaratkan dalam syarat pembayaran kredit. Semakin cepat syarat pembayaran kredit berarti semakin cepat terikatnya modal kerja tersebut dalam piutang dan berarti semakin besar tingkat Rasio Perputaran Piutang usaha dalam satu periode dan begitu pula sebaliknya.

Menurut Fahmi (2016:155) Dalam konsep piutang (receivable concept) semakin tinggi perputaran semakin baik, begitu pula sebaliknya semakin lambat Rasio Perputaran Piutang maka semakin tidak baik. Karena itu bagi suatu perusahaan untuk menaikkan angka penjualan salah satu caranya dengan menerapkan kebijakan piutang, termasuk memperlunak jangka waktu piutang. Misalnya dari 40 hari menjadi 55 hari, dan itu diikuti juga dengan memperbesar penjualan kredit misalnya dari 400 juta menjadi 650 juta.

Cara mencari rasio ini adalah dengan membandingkan antara penjualan kredit dengan rata-rata piutang.

\section{Rasio Perputaran Piutang}

$$
=\frac{\text { Penjualan Kredit }}{\text { Rata }- \text { rata Piutang }}
$$

Sumber: Sutrisno (2013:61)

Rasio ini dihitung dengan hanya memasukkan penjualan kredit karena penjualan kas tidak menimbulkan piutang. Karena laporan keuangan jarang mengungkapkan penjualan kas dan kredit secara terpisah, rasio ini sering kali harus 
dihitung dengan menggunakan angka penjualan bersih (yaitu, dengan mengasumsikan bahwa penjualan kas tidak signifikan). Piutang rata-rata dihitung dengan menambahkan saldo awal dan saldo akhir piutang pada periode tersebut dan membaginya dengan dua.

Rasio Perputaran Piutang yang semakin tinggi adalah semakin baik karena modal kerja yang ditanamkan dalam bentuk piutang akan semakin rendah. Naik turunnya Rasio Perputaran Piutang ini akan dipengaruhi oleh hubungan perubahan penjualan dengan perubahan piutang. Perubahan Rasio Perputaran Piutang dari tahun ke tahun atau perbedaan Rasio Perputaran Piutang antar perusahaan merupakan refleksi dari variasi kebijaksanaan pemberian kredit atau variasi tingkat kemampuan dalam pengumpulan piutang.

\section{Rasio Perputaran persediaan (Inventory Turnover)}

Setiap perusahaan yang menjalankan bisnisnya yaitu perusahaan dagang maupun perusahaan manufaktur pasti memiliki persediaan, dengan pengecualian perusahaan jasa. Persediaan sebagai bagian dari elemen modal kerja dan sebagai bagian dari aktiva lancar yang likuid dan penting setelah kas dan piutang. Menurut Murhadi (2013:19) Persediaan merupakan keseluruhan barang baik mulai dari bahan baku (raw material), barang setengah jadi (work in process) maupun barang jadi (finished good) yang masih ada diperusahaan dalam rangka proses bisnis perusahaan. Sedangkan menurut Jumingan (2011:18) berpendapat bahwa Persediaan merupakan barang dagangan yang dibeli untuk dijual kembali, yang masih ada ditangan pada saat penyusunan neraca.

Pendapat lainnya menurut Munawir (2014:16) menyatakan bahwa Persediaan untuk perusahaan perdagangan yang dimaksud dengan persediaan adalah semua barang-barang yang diperdagangkan untuk sampai tanggal neraca masih di gudang/belum laku dijual. Untuk perusahaan manufaktur (yang memproduksi barang), maka persediaan yang dimiliki meliputi persediaan bahan mentah, persediaan barang dalam proses dan persediaan barang jadi.

Dengan demikian dapat disimpulkan bahwa persediaan adalah bahan-bahan yang disediakan perusahaan untuk proses produksi dan barang-barang yang sudah jadi yang dimiliki perusahaan yang masih disimpan digudang perusahaan/belum laku terjual untuk memenuhi kebutuhan dan permintaan konsumen/pelanggan.

Menurut Hery (2012:244) Persediaan diklasifikasikan menurut perusahaannya yaitu persediaan untuk perusahaan dagang dan persediaan untuk perusahaan manufaktur. Untuk perusahaan dagang, persediaannya dinamakan barang dagangan, dimana barang dagangan ini dimiliki oleh perusahaan dan sudah langsung dalam bentuk siap untuk dijual dalam kegiatan bisnis normal perusahaan sehari-hari. Untuk perusahaan manufaktur, 
mula-mula persediaannya belum siap untuk dijual sehingga perlu diolah terlebih dahulu. Persediaannya diklasifikasikan menjadi tiga, yaitu bahan mentah, barang setengah jadi (barang dalam proses), dan barang jadi (produk akhir). Jadi dalam perusahaan manufaktur, perusahaanjenis ini terlebih dahulu akan mengubah (merakit) input atau bahan mentah (raw material) menjadi output atau barang jadi (finished goods/ final goods), baru kemudian dijual kepada para pelanggan (distributor).

Persediaan perlu mendapatkan perhatian khusus karena merupakan salah satu elemen modal kerja yang paling dibutuhkan dalam perusahaan dan juga merupakan komponen dari aktiva perusahaan yang langsung mempengaruhi laba, oleh karena itu perusahaan perlu menerapkan manajemen persediaan. Manajemen persediaan menyangkut kemampuan suatu perusahaan dalam mengatur dan mengelola perputarannya. Rasio Perputaran persediaan dalam perusahaan menunjukkan kinerja perusahaan dan efektivitas dari sebuah perusahaan dalam aktivitas operasionalnya.

Menurut Kasmir (2015:180) Rasio Perputaran persediaan merupakan rasio yang digunakan untuk mengukur berapa kali dana yang ditanam dalam persediaan (inventory) ini berputar dalam suatu periode.Menurut Harrison $\mathrm{Jr}$ et.all (2013:260) Rasio Perputaran persediaan (inventory turnover) yaitu mengukur berapa kali perusahaan menjual tingkat rata-rata persediaannya selama satu tahun. Perputaran yang cepat menunjukkan kemudahan dalam menjual persediaan, sementara perputaran yang rendah mengindikasi kesulitan dalam menjual persediaan. Sedangkan menurut Murhadi (2013:59) Rasio Rasio Perputaran persediaan (inventory turnover) mengindikasikan efisien perusahaan dalam memproses dan mengelola persediaannya. Rasio ini menunjukkan berapa kali persediaan barang dagangan diganti/ diputar dalam satu periode.

Kondisi perusahaan yang baik adalah dimana perusahaan memiliki persediaan dan perputarannya dalam kondisi yang seimbang. Jika nilai Rasio Perputaran persediaan terlalu tinggi, maka perusahaan memiliki jumlah persediaan yang kecil dan dapat menyebabkan kekurangan persediaan sehingga perusahaan tidak dapat memenuhi permintaan konsumen (pelanggan). Sebaliknya jika nilai perputaran rendah, maka akan merugikan perusahaan seperti resiko rusaknya persediaan dan menyebabkan turunnya harga jual suatu barang sehingga dapat menurunkan profitabilitas. Selain itu dengan adanya persediaan yang jumlahnya banyak perusahaan juga akan menanggung biaya penyimpanan yang relatif besar sehingga akan mengurangi profitabilitas perusahaan. Perusahaan berusaha untuk tidak selalu memperoleh tingkat perputaran yang paling tinggi, melainkan tingkat perputaran yang paling menguntungkan. 
Pada umumnya perusahaan berusaha menjual persediaannya secepat mungkin karena barang tidak akan menghasilkan laba sampai barang itu terjual. Semakin cepat persediaan terjual, semakin cepat kas masuk dan semakin tinggi pula laba yang akan diperoleh perusahaan dan hal sebaliknya untuk barang yang bergerak lambat. Di dalam perusahaan, Rasio Perputaran persediaan dapat menunjukkan kinerja perusahaan dalam aktivitas operasionalnya.

Menurut (Sutrisno, 2013:226) Adapun rumus Rasio Perputaran persediaan adalah sebagai berikut:

\section{Rasio Perputaran persediaan}

$$
=\frac{\text { Harga Pokok Penjualan }}{\text { Rata }- \text { rata Persediaan }}
$$

Demikian dapat disimpulkan bahwa Rasio Perputaran persediaan merupakan rasio yang digunakan untuk menilai dan mengukur berapa kali persediaan berputar dalam satu periode. Semakin tinggi Rasio Perputaran persediaan maka semakin baik bagi keadaan perusahaan, karena menunjukkan kinerja perusahaan berjalan secara efektif dan efisien serta produktif dalam penggunaan persediaan. Sebaliknya semakin rendah Rasio Perputaran persediaan maka membuat kondisi perusahaan tidak baik, hal ini dikarenakan memperbesar kerugiaan yang diterima perusahaan akibat penurunan harga, penambahan biaya penyimpanan dan pemeliharaan persediaan.

\section{Rasio Profitabilitas ROA}

Tujuan utama yang ingin dicapai suatu perusahaan adalah memperoleh laba atau keuntungan yang maksimal dan meningkatnya profitabilitas perusahaan. Profitabilitas suatu perusahaan dapat dinilai dan diukur dengan menghubungkan antara laba atau keuntungan yang diperoleh dari kegiatan operasional perusahaan dengan kekayaan atau aset yang digunakan untuk menghasilkan keuntungan tersebut.

Menurut Kasmir (2015:196) dijelaskan bahwa Rasio profitabilitas merupakan rasio untuk menilai dan mengukur kemampuan perusahaan dalam mencari keuntungan dalam suatu periode tertentu dan digunakan untuk memberikan ukuran tingkat efektifitas manajemen dan efisiensi suatu perusahaan.

Menurut Fahmi (2016:80) bahwa semakin baik rasio profitabilitas maka semakin baik menggambarkan kemampuan tingginya perolehan keuntungan perusahaan. Terdapat beberapa alat ukur atau rasio yang digunakan untuk mengukur profitabilitas, yaitu gross profit margin (GPM), net profit margin (NPM), return on investment (ROI) atau Rasio Profitabilitas (Return On Assets (ROA)) dan return on equity (ROE). Dapat disimpulkan bahwa profitabilitas adalah kemampuan perusahaan dalam meng-hasilkan laba atau keuntungan dan mengukur efektifitas manajemen perusahaan dalam menggunakan seluruh sumber daya secara keseluruhan yang telah diinvestasikan di dalam perusahaan untuk memperoleh keuntungan selama periode tertentu. 
Dalam penelitian ini penulis menggunakan rasio Return On Asset (ROA) untuk mengukur profitabilitas pada tingkat aset tertentu. Rasio Profitabilitas (Return On Assets (ROA)) adalah salah satu bentuk dari rasio profitabilitas yang dimaksudkan untuk mengukur dan menggambarkan kemampuan perusahaan untuk menghasilkan laba dengan keseluruhan dana yang ditanamkan dalam aset yang digunakan untuk operasional perusahaan. Menurut Kasmir (2015:201) Rasio Profitabilitas (Return On Assets (ROA)) merupakan rasio yang menunjukkan hasil (return) atas jumlah aktiva yang digunakan dalam perusahaan.

Menurut Harrison Jr et.all (2013:265) mengatakan tingkat pengembalian atas total aset atau Rasio Profitabilitas (Return On Assets (ROA)) merupakan rasio untuk mengukur keberhasilan perusahaan dalam menggunakan aset untuk menghasilkan laba.

Menurut Sutrisno (2013:229) Rasio Profitabilitas (Return On Assets (ROA)) juga sering disebut rentabilitas ekonomis merupakan kemampuan perusahaan dalam menghasilkan laba dengan semua aktiva yang dimiliki oleh perusahaan.

Menurut Munawir (2014:89) Rasio Profitabilitas (Return On Assets (ROA)) adalah salah satu bentuk dari rasio profitabilitas yang dimaksudkan untuk dapat mengukur kemampuan perusahaan dengan keseluruhan dana ditanamkan dalam aktiva yang digunakan untuk operasinya perusahaan untuk menghasilkan keuntungan.

Analisa Rasio Profitabilitas (Return On Assets (ROA)) mempunyai arti yang sangat penting dalam analisa laporan keuangan dan sudah biasa digunakan oleh pimpinan perusahaan untuk mengukur efektifitas dan efisien dari keseluruhan kegiatan operasi perusahaan.

Demikian dapat disimpulkan bahwa Rasio Profitabilitas (Return On Assets (ROA)) adalah rasio yang mencerminkan seberapa besar pengembalian yang diterima perusahaan dalam bentuk keuntungan atas investasi yang telah ditanamkan dalam perusahaan. Semakin tinggi nilai Rasio Profitabilitas (Return On Assets (ROA)) maka akan semakin baik keadaan perusahaan.

Adapun rumus yang digunakan untuk Return On Assets (Fahmi, 2016:82) adalah sebagai berikut:

$$
\text { ROA }=\frac{\text { Laba Bersih }}{\text { Total Aset }} x 100 \%
$$

\section{Kerangka Pemikiran}

Kerangka berfikir merupakan alur penelitian agar mudah dipahami. Kerangka berfikir dalam penelitian ini dapat digambarkan sebagai berikut: 


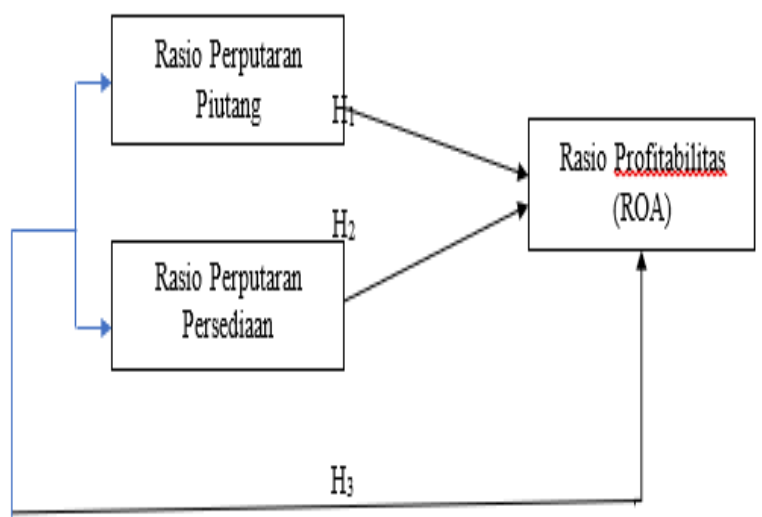

Gambar 1.1. Kerangka Berpikir

\section{Hipotesis Penelitian}

Hipotesis yang disusun dalam penelitian ini:

1. Ho : Rasio Rasio Perputaran Piutang tidak berpengaruh terhadap rasio profitabilitas yang diproyeksikan dengan ROA pada PT. Kalbe Farma Tbk.

Ha : Rasio Rasio Perputaran Piutang berpengaruh terhadap rasio profitabilitas yang diproyeksikan dengan ROA pada PT. Kalbe Farma Tbk.

2. Ho : Rasio Rasio Perputaran persediaan tidak berpengaruh terhadap rasio profitabilitas yang diproyeksikan dengan ROA pada PT. Kalbe Farma Tbk.

Ha : Rasio Rasio Perputaran persediaan tidak berpengaruh terhadap rasio profitabilitas yang diproyeksikan dengan ROA pada PT. Kalbe Farma Tbk.

3. Ho : Rasio Rasio Perputaran Piutang dan rasio Rasio Perputaran persediaan tidak berpengaruh terhadap rasio profitabilitas yang diproyeksikan dengan ROA pada PT. Kalbe Farma Tbk.

Ha : Rasio Rasio Perputaran Piutang dan rasio Rasio Perputaran persediaan tidak berpengaruh terhadap rasio profitabilitas yang diproyeksikan dengan ROA pada PT. Kalbe Farma Tbk.

\section{METODE}

\section{Metode Penelitian}

Metode yang digunakan yaitu pengujian statistik dengan analisis regresi linier berganda (multiple regression analysis), uji asumsi klasik, uji t dan uji $\mathrm{F}$ dengan menggunakan Statistical Product Service and Solutions (SPSS) versi 24.

\section{Populasi dan Sampel}

Populasi yang digunakan dalam penelitian ini adalah Laporan Keuangan PT. Kalbe Farma, Tbk. Sedangkan sampel adalah bagian dari jumlah dan karakteristik yang dimiliki oleh populasi tersebut (Sugiyono: 2015,81). Sampel dalam penelitian ini adalah Laporan Keuangan perusahaan berupa Neraca dan Laporan Laba Rugi PT. Kalbe Farma, Tbk dari tahun 2008 sampai dengan tahun 2017.

\section{Metode Analisis Data}

Metode analisis data yang digunakan dalam penelitian ini adalah dengan menggunakan analisis data kualitatif dan kuantitatif dengan penjelasan sebagai berikut:

\section{Uji Deskriptif}


Uji statistik deskriptif digunakan untuk memberikan gambaran variabel variabel yang diteliti. Uji statistik deskriptif mencakup nilai rata - rata (mean), nilai minimum, nilai maximum, nilai standar deviasi dari data perputaran piutang, perputaran persediaan, dan Return On Assets (ROA) pada tahun $2008-2017$.

\section{Uji Asumsi Klasik}

Uji asumsi klasik merupakan persyaratan statistik yang harus dipenuhi pada analisis regresi linier berganda yang berbasis ordinary least square (OLS). Untuk melakukan uji asumsi klasik terhadap data yang telah dikumpulkan, menggunakan analisis seperti beberapa uji asumsi klasik dibawah ini dengan bantuan program SPSS 24.00 (Statistical Product Service and Solutions). Uji asumsi klasik ini seperti Uji Normalitas; uji multikolinearitas, uji hereskedastisitas, dan uji autokorelasi.

\section{Analisis Regresi Linier Berganda}

Regresi Ganda adalah regresi dengan dua variabel bebas $\left(\mathrm{X}_{1}\right.$ dan $\left.\mathrm{X}_{2}\right)$ dan satu variabel terikat (Y) (Kusjono, 2015:150). Adapun bentuk persamaan Regresi berganda adalah $Y=a+b_{1} X_{1}+b_{2} X_{2}$ Dimana:

$\mathrm{Y}=$ Return On Assets (ROA)

$\mathrm{a}=$ Konstanta dari persamaan regresi

$\mathrm{X}_{1} \quad=$ Perputaran piutang

$\mathrm{X}_{2} \quad=$ Perputaran persediaan

$b_{1}, b_{2}=$ Koefisien regresi

\section{HASIL dan PEMBAHASAN}

\section{Hasil}

\section{Perhitungan Rasio Perputaran Piutang}

Perputaran Piutang $=\frac{\text { Penjualan Kredit }}{\text { Rata }- \text { rata Piutang }}$ $\operatorname{PP}(2008)=\frac{7 \cdot 877 \cdot 366 \cdot 385 \cdot 633}{902 \cdot 464 \cdot 865.941}=8,73 \mathrm{kali}$ $\operatorname{PPi}(2009)=\frac{9.087 \cdot 347 \cdot 669 \cdot 804}{1.069 \cdot 649 \cdot 106 \cdot 236}=8,50 \mathrm{kali}$ $\operatorname{PPi}(2010)=\frac{10 \cdot 226 \cdot 789 \cdot 206 \cdot 223}{1 \cdot 233 \cdot 325 \cdot 750 \cdot 367}=8,29 \mathrm{kali}$ $\operatorname{PPi}(2011)=\frac{10 \cdot 911 \cdot 860 \cdot 141 \cdot 523}{1 \cdot 396 \cdot 351 \cdot 149 \cdot 630,5}=7,81 \mathrm{kali}$ $\operatorname{PPi}(2012)=\frac{13 \cdot 636 \cdot 405 \cdot 178 \cdot 957}{1 \cdot 667 \cdot 613 \cdot 294 \cdot 675}=8,18 \mathrm{kali}$ $\operatorname{PPi}(2013)=\frac{16 \cdot 002 \cdot 131 \cdot 057 \cdot 048}{1 \cdot 975 \cdot 226 \cdot 932 \cdot 611}=8,10 \mathrm{kali}$ $\operatorname{PPi}(2014)=\frac{17 \cdot 368 \cdot 532 \cdot 547 \cdot 558}{2 \cdot 246 \cdot 081 \cdot 278 \cdot 863,5}=7,73 \mathrm{kali}$ $\operatorname{PPi}(2015)=\frac{17 \cdot 887 \cdot 464 \cdot 223 \cdot 321}{2 \cdot 350.861 .712 .592}=7,61 \mathrm{kali}$ $\operatorname{PPi}(2016)=\frac{19.374 \cdot 230 \cdot 957 \cdot 505}{2.492 \cdot 993 \cdot 100 \cdot 521,5}=7,77 \mathrm{kali}$ $\operatorname{PPi}(2017)=\frac{20 \cdot 182 \cdot 120 \cdot 166 \cdot 616}{2 \cdot 753 \cdot 811 \cdot 888 \cdot 879}=7,33$ kali

\section{Perhitungan Rasio Perputaran Persediaan}

Perp Persediaan

$$
=\frac{\text { Harga Pokok Penjualan }}{\text { Rata }- \text { rata Persediaan }}
$$

PPe $(2008)=\frac{4 \cdot 073 \cdot 725 \cdot 872 \cdot 514}{1 \cdot 516 \cdot 595 \cdot 933 \cdot 297}=2,69 \mathrm{kali}$

$\operatorname{PPe}(2009)=\frac{4.575 .407 .367 .444}{1.583 .753 .150 .341,5}$

$$
=2,89 \mathrm{kali}
$$

$\operatorname{PPe}(2010)=\frac{5 \cdot 060 \cdot 403 \cdot 621 \cdot 307}{1 \cdot 556 \cdot 105 \cdot 619.316}=3,25 \mathrm{kali}$ $\operatorname{PPe}(2011)=\frac{5.360 \cdot 686 \cdot 806.582}{1.628 .009 .003 .073}=3,29 \mathrm{kali}$ $\operatorname{PPe}(2012)=\frac{7 \cdot 102 \cdot 971 \cdot 372 \cdot 126}{1 \cdot 910 \cdot 336 \cdot 476 \cdot 610}=3,72$ kali $\operatorname{PPe}(2013)=\frac{8.323 .017 \cdot 600.990}{2.584 .489 .140 .380,5}$

$$
=3,22 \text { kali }
$$

$\operatorname{PPe}(2014)=\frac{8 \cdot 892 \cdot 725 \cdot 955 \cdot 545}{3.072 \cdot 019.332 .503}=2,89 \mathrm{kali}$

$\operatorname{PPe}(2015)=\frac{9.295 \cdot 887.287 \cdot 351}{3.046 .846 .843 .413}=3,05$ kali

$\operatorname{PPe}(2016)=\frac{9.886 \cdot 262 \cdot 652 \cdot 473}{3 \cdot 173 \cdot 776.843 .388}=3,11 \mathrm{kali}$

PPe $(2017)=\frac{10.369 .836 .693 .616}{3.450 .950 .394 .661,5}$ $=3,00$ kali 
3. Perhitungan Rasio Profitabilitas (ROA)

$$
\begin{aligned}
& \text { ROA }=\frac{\text { Laba Bersih }}{\text { Total Aset }} \times 100 \% \\
& \operatorname{ROA}(2008)=\frac{706.822 .146 .190}{5.703 .832 .411 .898} \times 100 \% \\
& =12,39 \% \\
& \operatorname{ROA}(2009)=\frac{929.003 .740 .338}{6.482 .446 .670 .172} \times 100 \% \\
& =14,33 \% \\
& \operatorname{ROA}(2010)=\frac{1.286 .330 .026 .012}{7.032 .496 .663 .288} \times 100 \% \\
& =18,29 \% \\
& \operatorname{ROA}(2011)=\frac{1.522 .956 .820 .292}{8.274 .554 .112 .840} \times 100 \% \\
& =18,41 \% \\
& \operatorname{ROA}(2012)=\frac{1.775 .098 .847 .932}{9.417 .957 .180 .958} \times 100 \% \\
& =18,85 \% \\
& \operatorname{ROA}(2013)=\frac{1.970 .452 .449 .686}{11.315 .061 .275 .026} \times 100 \% \\
& =17,41 \% \\
& \operatorname{ROA}(2014)=\frac{2.121 .090 .581 .630}{12.425 .032 .367 .729} \times 100 \% \\
& =17,07 \% \\
& \operatorname{ROA}(2015)=\frac{2.057 .694 .281 .873}{13.696 .417 .381 .439} \times 100 \% \\
& =15,02 \% \\
& \operatorname{ROA}(2016)=\frac{2.350 .884 .933 .551}{15.226 .009 .210 .657} \times 100 \% \\
& =15,44 \% \\
& \operatorname{ROA}(2017)=\frac{2.453 .251 .410 .604}{16.616 .239 .416 .335} \times 100 \% \\
& =14,76 \%
\end{aligned}
$$

Tabel 1.2. Data Perputaran Piutang, Perputaran Persediaan dan Return On Assets (ROA) PT. Kalbe Farma, Tbk Periode 2008-2017

\begin{tabular}{|c|c|c|c|}
\hline $\begin{array}{c}\text { Perio } \\
\text { de }\end{array}$ & $\begin{array}{c}\text { Perputaran } \\
\text { Piutang } \\
\text { (kali) }\end{array}$ & $\begin{array}{c}\text { Perputaran } \\
\text { Persediaan } \\
\text { (kali) }\end{array}$ & $\begin{array}{c}\text { ROA } \\
\text { (\%) }\end{array}$ \\
\hline 2008 & 8,73 & 2,69 & 12,39 \\
\hline 2009 & 8,50 & 2,89 & 14,33 \\
\hline 2010 & 8,29 & 3,25 & 18,29 \\
\hline 2011 & 7,81 & 3,29 & 18,41 \\
\hline 2012 & 8,18 & 3,72 & 18,85 \\
\hline 2013 & 8,10 & 3,22 & 17,41 \\
\hline 2014 & 7,73 & 2,89 & 17,07 \\
\hline 2015 & 7,61 & 3,05 & 15,02 \\
\hline 2016 & 7,77 & 3,11 & 15,44 \\
\hline 2017 & 7,33 & 3,00 & 14,76 \\
\hline
\end{tabular}

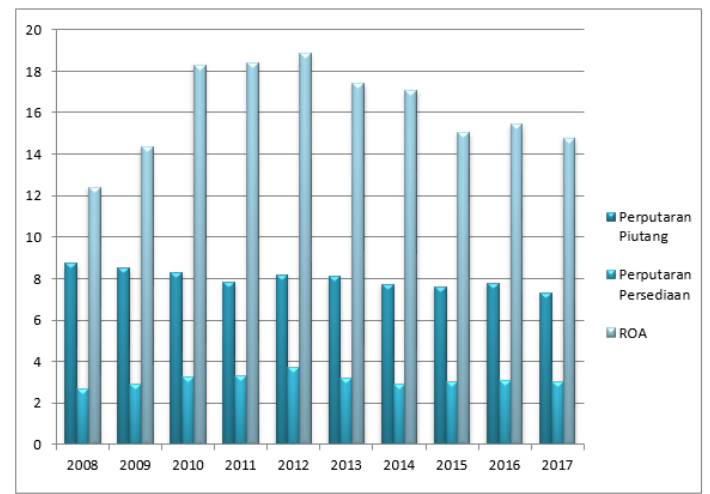

Gambar 1.2. Grafik Perputaran Piutang, perputaran Persedian dan ROA

\section{Uji Asumsi Klasik}

\section{Uji Normalitas}

Hasil pengujian normalitas data pada variabel Perputaran piutang dan Perputaran persediaan terhadap Return On Assets (ROA) diperoleh hasil sebagai berikut:

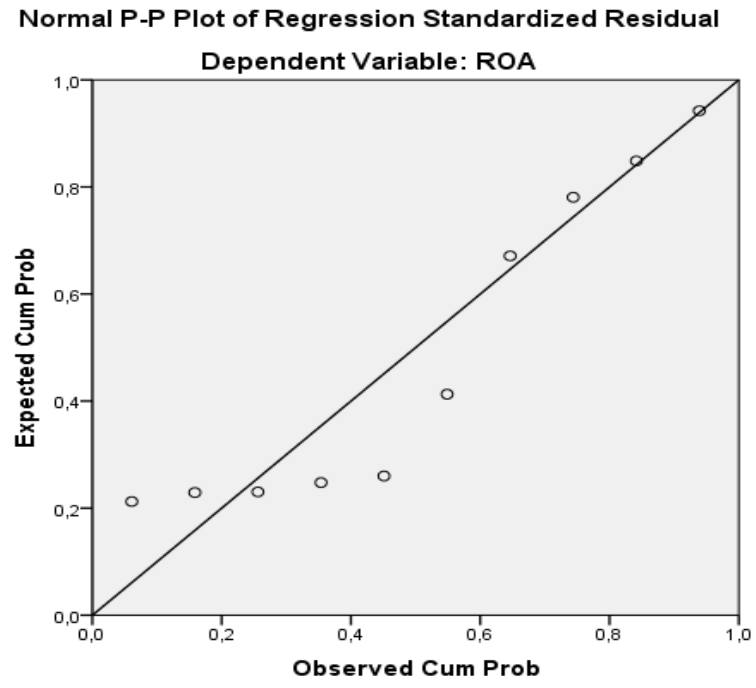

Gambar1.3. Normal P-Plot

Dari gambar di atas menunjukkan bahwa titik-titik menyebar disekitar garis diagonal dan mengikuti arah garis diagonal. Sehingga dapat disimpulkan bahwa model regresi layak dipakai dalam penelitian karena telah memenuhi asumsi normalitas. 


\section{Uji Multikolinearitas}

Uji Multikolinearitas bertujuan untuk menguji apakah model regresi ditemukan adanya korelasi antara variabel bebas (Independent). Berikut dapat dilihat dari tabel dibawah ini:

\begin{tabular}{|c|c|c|}
\hline \multicolumn{3}{|c|}{ Tabel 1.3. Hasil Uji Multikolinearitas } \\
\hline \multicolumn{3}{|c|}{ COEFFICIENTS $^{\mathrm{A}}$} \\
\hline \multirow[b]{2}{*}{ Model } & \multicolumn{2}{|c|}{ Collinearity Statistics } \\
\hline & Tolerance & VIF \\
\hline 1 (Constant) & & \\
\hline Perputaran Piutang & 985 & 1,015 \\
\hline $\begin{array}{l}\text { Perputaran } \\
\text { Persediaan }\end{array}$ &, 985 & 1,015 \\
\hline
\end{tabular}

Dari tabel di atas, dapat diketahui bahwa nilai tolerance Perputaran piutang dan Perputaran persediaan $>10 \%$ serta nilai VIF Perputaran piutang dan Perputaran persediaan < 10. Jadi dapat disimpulkan bahwa tidak ada multikolinearitas antar variabel independen dalam model regresi.

\section{Uji Heteroskedastisitas}

Uji heteroskedastisitas bertujuan untuk menguji apakah dalam model regresi terjadi ketidaksamaan variasi dan residual suatu pengamatan ke pengamatan lain. Model regresi yang baik adalah homoskedastisitas atau tidak terjadi heteroskedastisitas.

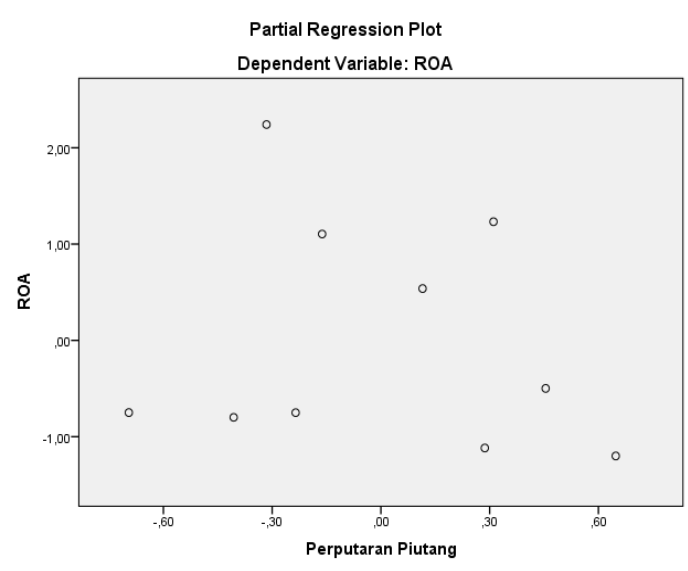

Gambar 1.4. Scatterplot Perputaran Piutang

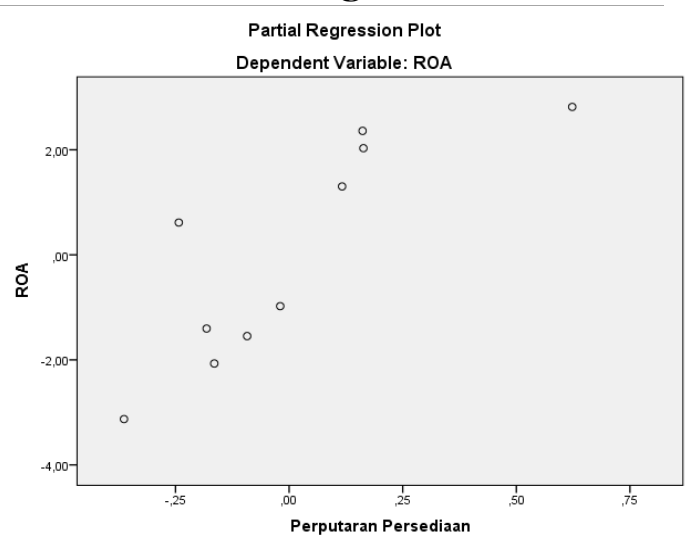

Gambar 1.5. Scatterplot Perputaran Persediaan

Dari gambar di atas, dapat diketahui bahwa titik-titik menyebar diatas dan dibawah titik o pada sumbu Y dan tidak membentuk pola tertentu, maka dapat disimpulkan bahwa model regresi yang terbentuk diidentifikasi tidak terjadi gejala heteroskedastisitas. Sehingga model regresi layak dipakai dalam penelitian karena telah memenuhi asumsi-asumsi dalam Uji

Heteroskedastisitas.

\section{Uji Autokorelasi}

Uji Autokorelasi digunakan untuk melihat apakah variabel $\mathrm{X}$ dan Variabel $\mathrm{Y}$ saling menggangu. Salah satu cara 
untuk mendeteksi ada atau tidaknya autokorelasi yaitu dengan melakukan uji Durbin-Watson (DW Test) (Ghozali, 2011:110). Ketentuan yang menjadi dasar terjadinya autokorelasi jika nilai Durbin-Watson (DW) antara 1 sampai 3 (Arifin, 2017:151). Berikut dapat dilihat pada tabel dibawah ini:

Tabel 1.4. Hasil Uji Autokorelasi Model Summary ${ }^{\mathrm{b}}$

\begin{tabular}{|c|c|c|c|c|c|}
\hline Model & $R$ & $\begin{array}{c}\mathrm{R} \\
\text { Square }\end{array}$ & $\begin{array}{c}\text { Adjusted R } \\
\text { Square }\end{array}$ & $\begin{array}{c}\text { Std. Error } \\
\text { of the } \\
\text { Estimate }\end{array}$ & $\begin{array}{l}\text { Durbin- } \\
\text { Watson }\end{array}$ \\
\hline 1 & $833 a$ & 694 &, 606 & 1,33201 & 1,745 \\
\hline
\end{tabular}

Berdasarkan tabel di atas, diketahui bahwa nilai Durbin-Watson menunjukkan nilai 1,745 artinya bahwa model penelitian tidak terjadi autokorelasi, yang artinya model ini dapat dilanjutkan dalam analisis regresi nilai berganda.

\section{Analisis Regresi Linier Berganda} Tabel 1.5. Hasil Uji Analisis Regresi Linier Berganda

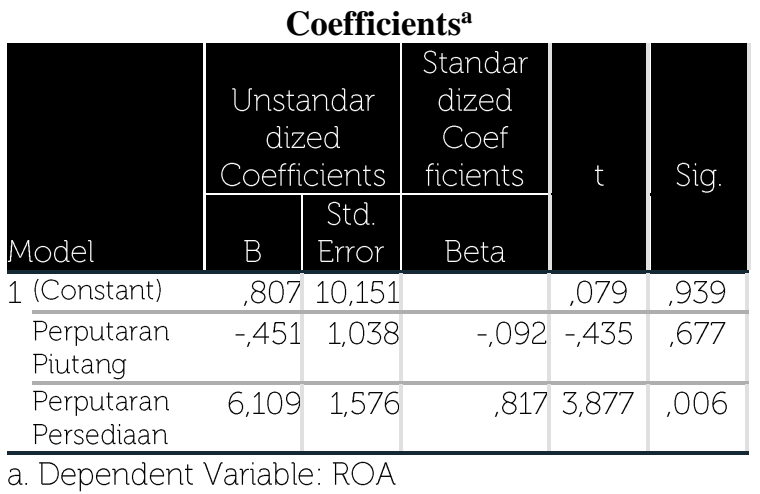

Persamaan regresi yang dapat disusun dari output di atas $\mathrm{Y}=0,807-0,451 \mathrm{X}_{1}$ $+6,109 \mathrm{X}_{2}$ atau $\mathrm{ROA}=0,807-0,451$ (Perputaran Piutang) $+6,109$ (Perputaran Persediaan)

\section{Uji Koefisien Determinasi (KD)}

\begin{tabular}{|c|c|c|c|c|c|}
\hline \multicolumn{6}{|c|}{$\begin{array}{c}\text { Tabel 1.6. Hasil Uji } \\
\text { Koefisien Determinasi }\end{array}$} \\
\hline Model & $\mathrm{R}$ & $\begin{array}{c}\mathrm{R} \\
\text { Square }\end{array}$ & $\begin{array}{c}\text { Adjuste } \\
\text { d R } \\
\text { Square }\end{array}$ & $\begin{array}{c}\text { Std. Error of } \\
\text { the } \\
\text { Estimate }\end{array}$ & $\begin{array}{l}\text { Durbin- } \\
\text { Watson }\end{array}$ \\
\hline 1 &, 833 & 694 & .606 & 1,33201 & 1,745 \\
\hline
\end{tabular}

Berdasarkan di atas, maka diketahui nilai koefisien determinasi variabel Perputaran piutang dan Perputaran persediaan terhadap Return On Assets (ROA) sebesar 0,694. Artinya bahwa kedua variabel independen (Perputaran piutang dan Perputaran persediaan) mempunyai kontribusi yang kuat terhadap variabel dependen Return On Assets (ROA) sebesar $69,4 \%$. Sedangkan sisanya yaitu sebesar 30,6\% dipengaruhi oleh variabel lain diluar penelitian. Dengan kata lain, Perputaran piutang dan Perputaran persediaan bukan satu-satunya faktor yang mampu mempengaruhi Return On Assets (ROA) namun terdapat variabel lain yang juga memiliki kontribusi dalam meningkatkan Return On Assets (ROA).

\section{Uji Hipotesis}

\section{Uji Parsial (Uji-t)}

Uji $\mathrm{t}$ digunakan untuk mengetahui seberapa besar signifikansi masing-masing variabel independent berpengaruh terhadap variabel depedent secara parsial. Sebagai pembanding untuk melihat pengaruh signifikan, maka digunakan kriteria taraf signifikan sebesar 5\% (0,05) dan membandingkan $t_{\text {hitung }}$ dengan $t_{\text {tabel }}$ dengan kriteria sebagai berikut. Jika $t_{\text {hitung }}$ 
lebih besar dari pada $t_{\text {tabel}}$, atau t-siginifikan level dibawah 5\%, maka variabel $\mathrm{X}$ berpengaruh signifikan terhadap variabel Y.

Tabel 1.7.Hasil Uji T Parsial Coefficients $^{\mathrm{a}}$

\begin{tabular}{|c|c|c|c|c|c|}
\hline Model & $\begin{array}{l}\text { Unstan } \\
\text { Coef } \\
\text { B }\end{array}$ & $\begin{array}{l}\text { ndardized } \\
\text { fficients } \\
\text { Std. Error }\end{array}$ & $\begin{array}{c}\text { Standardized } \\
\text { Coefficients } \\
\text { Beta }\end{array}$ & t & Sig. \\
\hline 1 (Constant) & 807 & 10,151 & & .079 & \\
\hline $\begin{array}{l}\text { Perputaran } \\
\text { Piutang }\end{array}$ &,- 451 & 1,038 &,- 092 &,- 435 & 677 \\
\hline $\begin{array}{l}\text { Perputaran } \\
\text { Persediaan }\end{array}$ & 6,109 & 1,576 & 817 & 3,877 & .006 \\
\hline
\end{tabular}

Berdasarkan hasil pengujian melalui SPSS diatas maka dapat disimpulkan hasilnya adalah sebagai berikut:

1. Variabel perputaran piutang memiliki nilai Sig. 0,677 > 0,05 dan nilai $t_{\text {hitung }}$ lebih kecil $(<)$ dari pada $t_{\text {tabel }}$ atau sebesar (o,435 < 2,365). Jadi, dapat disimpulkan bahwa secara parsial Perputaran piutang tidak berpengaruh terhadap Return On Assets (ROA).

2. Variabel perputaran persediaan memiliki nilai Sig. 0,006 < 0,05 dannilai $t_{\text {hitung }}$ lebih besar ( $>$ ) dari pada $t_{\text {tabel }}$ atau sebesar $(3,877>2,365)$. Jadi, dapat disimpulkan bahwa ada pengaruh yang signifikan antara perputaran persediaan terhadap Return On Assets (ROA).

\section{Uji Simultan (Uji F)}

Untuk menguji secara bersama-sama variabel Perputaran piutang $\left(\mathrm{X}_{1}\right)$ dan Perputaran persediaan $\left(\mathrm{X}_{2}\right)$ terhadap Return On Assets (ROA) (Y), dapat dilakukan dengan uji statistik F (Uji Simultan). Sebagai pem-banding untuk melihat pengaruh signifikan, maka digunakan kriteria tarif signifikan sebesar $5 \%$ atau 0,05. Hhasil pengolahan data terhadap pengujian statistik F, dapat dilihat pada tabel-tabel dibawah ini:

Tabel 1.8. Hasil Uji F Simultan ANOVA $^{a}$

\begin{tabular}{|c|c|c|c|c|c|c|}
\hline & Model & $\begin{array}{l}\text { Sum of } \\
\text { Squares }\end{array}$ & Df & $\begin{array}{l}\text { Mean } \\
\text { Square }\end{array}$ & $F$ & Sig. \\
\hline \multirow[t]{3}{*}{1} & Regression & 28,132 & 2 & 14,066 & 7,928 & $016^{b}$ \\
\hline & Residual & 12,420 & 7 & 1,774 & & \\
\hline & Total & 40,552 & 9 & & & \\
\hline \multicolumn{7}{|c|}{ a. Dependent Variable: ROA } \\
\hline \multicolumn{7}{|c|}{$\begin{array}{l}\text { b. Predictors: (Constant), Perputaran Persediaan, } \\
\text { Perputaran Piutang }\end{array}$} \\
\hline
\end{tabular}

Dari tabel di atas dapat diketahui nilai $\mathrm{F}_{\text {hitung }}$ untuk model regresi yang diperoleh sebesar 7,928 dengan nilai signifikan sebesar $(0,016<0,05)$ dan tabel F diperoleh dengan $\mathrm{df}_{1}=2$ dan $\mathrm{df}_{2}=7$ sebesar 4,737. Hasil uji pengaruh perputaran piutang dan perputaran persediaan diperoleh $\mathrm{F}_{\text {hitung }}$ $(7,928)>F_{\text {tabel }}(4,737)$. Hal ini memberikan penjelasan bahwa Perputaran piutang dan Perputaran persediaan secara bersamasama berpengaruh positif dan signifikan terhadap Return On Assets (ROA).

\section{Pembahasan}

1. Variabel perputaran piutang secara parsial tidak berpengaruh terhadap Return On Assets (ROA) dengan nilai Sig. 0,677 > 0,05 dan nilai $t_{\text {hitung }}$ lebih kecil $(<)$ dari pada $t_{\text {tabel }}$ atau sebesar $(-$ $0,435<2,365)$.

2. Variabel perputaran persediaan secara parsial berpengaruh dan signifikan terhadap Return On Assets (ROA) dengan nilai Sig. 0,006 < 0,05 dan nilai $t_{\text {hitung }}$ lebih besar $(>)$ dari pada $t_{\text {tabel }}$ atau sebesar $(3,877>2,365)$. 
3. Secara Simultan variabel perputaran piutang dan perputaran persediaan berpengaruh positif dan signifikan terhadap Return On Assets (ROA) dengan persamaan regresi $\mathrm{Y}=0,807$ $0,451 X_{1}+6,109 X_{2}$. Hasil uji $F$ diperoleh diperoleh $F_{\text {hitung }}(7,928)>F_{\text {tabel }}(4,737)$ dengan nilai signifikan sebesar $(0,016<$ 0,05). Adapun konstribusi yang diberikan variabel perputaran piutang dan perputaran persediaan Return On Assets (ROA) sebesar 69,6\%.

\section{SIMPULAN}

\section{Kesimpulan}

1. Hasil Uji t pengaruh Perputaran piutang terhadap Return On Assets (ROA) diperoleh nilai $t_{\text {hitung }}$ lebih kecil $(<)$ dari pada $t_{\text {tabel }}$ atau sebesar $(-0,435<2,265)$ dan nilai Sig. 0,677>0,05. Artinya secara parsial perputaran piutang tidak berpengaruh dan tidak signifikan terhadap Return On Assets (ROA).

2. Hasil Uji $t$ pengaruh perutaran persediaan terhadap Return On Assets (ROA) diperoleh nilai thitung lebih besar $(>)$ dari pada $t_{\text {tabel }}$ atau sebesar $(3,877>$ 2,365) dan nilai Sig. 0,006 < 0,05. Artinya secara parsial perputaran persediaan ber-pengaruh positif dan signifikan terhadap Return On Assets (ROA).

3. Hasil Uji F pengaruh Perputaran piutang dan Perputaran persediaan terhadap Return On Assets (ROA) diperoleh nilai $\mathrm{F}_{\text {hitung }}$ lebih besar $(>)$ dari $\mathrm{F}_{\text {tabel }}$ atau sebesar $(7,928>4,737)$ dan nilai Sig.
0,016 < 0,05 dengan persamaan regresi $\mathrm{Y}=0,807-0,451 \mathrm{X}_{1}+6,109 \mathrm{X}_{2}$. Artinya secara simultan perputaran piutang dan per-putaran persediaan secara bersamasama berpengaruh signifikan terhadap Return On Assets (ROA) dengan konstribusi sebesar 69,4\%.

\section{Saran}

Beberapa saran yang dapat disampaikan antara lain:

1. Dilihat dari tingkat perputaran piutang, perusahaan disarankan agar lebih memperhatikan dan memperbaiki perputaran piutang agar lebih cepat perputarannya atau meningkat dengan cara menaikkan aktivitas kebijakan penagihan piutang kepada pelanggan atau memperketat syarat pembayaran pen-jualan kredit sehingga perusahaan tidak memperbesar resiko atas pinjaman ataupun penjualan secara kredit.

2. Dilihat dari tingkat perputaran persediaan, manajemen persediaan sudah cukup baik meski masih mengalami fluktuatif tetapi cenderung meningkat setiap tahunnya. Perusahaan masih harus tetap memperhatikan manajemen persediaan dengan mengelola persediaan secara efektif dan efisien, meningkatkan promosi dan pemasaran agar perputaran persediaan terus meningkat sehingga keuntungan perusahaan juga meningkat.

3. Dilihat dari nilai Return On Assets (ROA), perusahaan disarankan untuk terus meningkatkan perolehan laba 
setiap tahunnya. Peningkatan perolehan laba bisa dilakukan salah satu caranya yaitu perusahaan membuat program peng-hematan biaya. Dimana biaya harus dikontrol pengeluarannya jangan sampai melebihi anggaran biaya serta perusahaan harus mampu mengelola pemanfaatan aset secara lebih efektif lagi.
Sugiyono. Metode Penelitian Kuantitatif, Kualitatif, dan R\&D. Cetakan Ke-22. Bandung: Alfabeta. 2015

Warren, Reeve, dan Fess. 2008. Pengantar Akuntansi. Edisi 21. Jakarta: Salemba Empat.

www.idx.co.id. www.kalbe.co.id.

\section{DAFTAR PUSTAKA}

Fahmi, Irham. Pengantar Manajemen Keuangan: Teori dan Soal Jawab. Cetakan Kelima. Bandung: Alfabeta. 2016

Harrison Jr. Walter T, Charles T. Horngren, C.William Thomas, dan Themin Suwardy. Akuntansi Keuangan. Jilid 2, Edisi 8. Jakarta: Erlangga. 2013

Hery. Pengantar Akuntansi 1. Jakarta: Lembaga Penerbit Fakultas Ekonomi Universitas Indonesia. 2012

Kasmir. Analisis Laporan Keuangan. Edisi 1, Cetakan 8. Jakarta: PT. Rajagrafindo Persada. 2015

Munawir. Analisa Laporan Keuangan.

Yogyakarta: PT. Liberty Yogyakarta. 2014

Murhadi, Werner R. Analisis Laporan Keuangan Proyeksi dan Valuasi Saham. Jakarta: Salemba Empat. 2013

Raharjaputra, Hendra. Manajemen Keuangan dan Akuntansi.Jakarta: Salemba Empat. 2009 